\title{
The construct and predictive validity testing of Indonesian entrepreneurial competence inventory-situational judgment test model
}

\author{
Benedicta Prihatin Dwi Riyanti ${ }^{1}$, Angela Oktavia Suryani ${ }^{*}$ (D), Christine Winstinindah Sandroto ${ }^{1}$ and \\ Silverius Y. Soeharso
}

\author{
*Correspondence: \\ angela.suryani@atmajaya. \\ ac.id \\ ${ }^{1}$ Atma Jaya Catholic \\ University of Indonesia, \\ Jakarta, Indonesia \\ Full list of author information \\ is available at the end of the \\ article
}

\begin{abstract}
This research aimed to test the internal and external validity of the Indonesian Entrepreneurial Competence Inventory constructed based on the situational judgment test (SJT) model. Spencer's entrepreneurial competence theory and interviews with entrepreneurs were employed to build the items. The internal construct validity was tested by applying confirmatory factor analysis (CFA). In contrast, the external construct validity was tested by implementing correlations with other tests that were theoretically correlated with entrepreneurial competency, namely, the previous entrepreneurial competence (Likert-scale model) and risk behavior. The predictive validity was analyzed using correlation testing with an instrument assessing balanced scorecard measurement of entrepreneurial achievement. A sample of 149 entrepreneurs from industrial cities in Indonesia was recruited via convenience sampling. The CFA analyses showed that nine dimensions of the Indonesian Entrepreneurial Competencies Inventory were valid. In the correlation testing with risk-taking behavior and business success, all dimensions were significantly valid, except the see and act on opportunity dimension. However, in the correlation with the previous entrepreneurial competence scale, a significant correlation was found only with a commitment to work. In further analysis, the correlation between dimensions of the current inventory and dimensions of the previous scale showed significant correlations between the competence of seeing opportunity and commitment to work, assertiveness, and persuasion. The impact to the future research and practice application were discussed.
\end{abstract}

Keywords: Indonesian entrepreneurial competence inventory, Situational judgment test, Construct validity, Predictive validity, Confirmatory factor analysis

\section{Background}

The emphasis on human resource development in the second-term government of the President of Indonesia 2020-2024 (Machmudin, 2017) is a significant momentum that cannot be ignored. The government understands that it is time for Indonesia to develop a strategy to improve human resources (HR) competence in a more directed and sincere manner. Two of the potential human resources to be developed are entrepreneurship and aspiring entrepreneurs. Therefore, creating small and medium enterprises (SMEs) author(s) and the source, provide a link to the Creative Commons licence, and indicate if changes were made. The images or other third party material in this article are included in the article's Creative Commons licence, unless indicated otherwise in a credit line to the material. If material is not included in the article's Creative Commons licence and your intended use is not permitted by statutory regulation or exceeds the permitted use, you will need to obtain permission directly from the copyright holder. To view a copy of this licence, visit http:// creativecommons.org/licenses/by/4.0/. 
is one of the government's strategic priorities to support the attainment of the Industrial Revolution 4.0 (Antara \& Setiawan, 2018). SMEs were chosen, because 70\% of Indonesian work in SMEs, according to the Ministry of Industry.

The support from the government can be seen from the permission given to entrepreneurs to open e-business, developing infrastructure for technology development related to e-commerce and bank technology, and mentoring for innovation in e-business. The main objective of government support is to enhance the quality of SMEs to achieve excellent performance. The determinants of the success/failure of an entrepreneur are defined from many dimensions, including personal, organizational, and external factors. However, the fundamental aspect lies in individual vision, intention, and work that will turn business ideas into the reality of success. The businessperson integrates financial and human resources to organize, produce, and develop companies through organizing their customers and workers (León \& Gorgievski, 2007). The excellent performance of a business is a performance that is based on the presence of competence at work.

Competence is defined as the individual's knowledge, skills, and ability (personality) directly affecting performance (Spencer \& Spencer, 1993). It includes individual features that correlate with the actual outcome of a given duty or task and in an individual's behavior; thus, it can be observed and measured. It enables the achievement of aims and goals. Competencies are assets in any corporate, and they can be nurtured or cultivated (Irene, 2017). In the field of entrepreneurship, Spencer and Spencer (1993) described 13 entrepreneurial competencies. Meanwhile, Chou et al. (2010) defined entrepreneurial competence as the essential requirement for an entrepreneur. Entrepreneurial competence has been proven to make a real contribution to business success (Man \& Lau, 2005).

According to León and Gorgievski (2007), competencies will play an essential role in the entrepreneurial process. The higher competency is associated with higher ability in entrepreneurship. It was further explained that competence affects the ability of an entrepreneur to see opportunity, take it, and create projects to respond to the opportunity. The ability to make a project is influenced by how many and how good competencies they have. Although it is not only competence that determines the success of a business, people with high competence will also do better or achieve several advantages over people who do not have that competence at all. In the current situation, being creative, imaginative, and innovative are crucial to sustaining the business (Juliana et al., 2021). The globalization of many lives' aspects and the advancement of technology drive the marketplace to become more crowded and competitive. A business person should be able to see and catch the opportunity to take advantage.

In line with Leon and Gorgievski (2007) statement, entrepreneurship education and development should be based on competence. To find whether someone already has entrepreneurial competence, a measurement tool is needed. Entrepreneurial competence inventory is a tool that can identify the level of competence of prospective entrepreneurs and entrepreneurs. This measure of entrepreneurial competence can be a means of detecting whether a person has the skills needed to become an entrepreneur.

The need to develop a measurement tool for entrepreneurial competencies in the Indonesian context is driven by the reality that various entrepreneurship programs promoted by the government to reduce unemployment and economic deprivation 
due to poverty have not shown significant results. The number of entrepreneurs in Indonesia is only $3.3 \%$ of the total population of Indonesians. Meanwhile, the percentage of the open unemployment rate of university graduates has risen from 5.34 to $6.22 \%$. This data shows the need for new job orientation, one of which is becoming an entrepreneur.

León and Gorgievski (2007) explained that the most significant determinant of business success is personal characteristics (individual differences). The businesspersons determine all decisions and actions to maintain the company's sustainability developed. To develop excellent entrepreneurs, there should be a program with a standardized curriculum enhancing the competencies of potential entrepreneurs. The program should include modules increasing competencies; these competencies should be identified and measured. A way to understand the competencies is using a valid instrument. Wulani et al. (2019) noted that most of the entrepreneurial research in Indonesia implemented tools created in other cultures. Only two devices measured entrepreneurial competencies based on Indonesian culture, namely, self-assessment entrepreneurial competencies by Riyanti and Suwartono (2018) and Wulani et al. (2019). The reason to build an instrument contextual Indonesia was that culture constructs human behavior, values, beliefs, and needs (see Cronk, 2017). External factors also influence entrepreneurship competencies, namely, physical and sociocultural environments (Wulani et al., 2019). Their instruments used the summated rating scale method (Likert-scale type), a self-report model measuring to what extent the participant agreed or disagreed with the statements. Although these instruments were valid and reliable, the statements were more measuring perceptions rather than actual competence (i.e., includes problem-solving ability). Suryani et al. (2021) constructed a new entrepreneurial competency instrument in the situational judgment test model by considering the need to measure actual competencies. This instrument consists of cases and four options solutions; the participants should choose one of the solutions. The problem and relevant solutions were derived from interviews with the owner of SME).

They wrote 114 items of entrepreneurship competencies based on 13 dimensions of entrepreneurship described by Spencer and Spencer (1993) and interviews with entrepreneurs (provide additional one dimension, namely, care). The items were constructed in the form of a situational judgment test model. In this model, the stimulus was a short description of an entrepreneur's experience containing conflict/problem during his/ her business. The response to the problems was displayed in multiple-choice form. The alternative of choices was derived from the solutions provided by successful entrepreneur experiences and the judgment of academic experts on entrepreneurship. In their study, through internal validity examination by implementing homogeneity item analysis (corrected item-total correlations), there were 64 items remains representing 13 dimensions. However, they found a dimension that only has 1 item, namely, use influencing others strategy; therefore, this dimension was dropped. In their study, an exploratory factor analysis (EFA) was conducted to discover a shorter dimension for a quick diagnostic of an entrepreneur's competence. The EFA analysis revealed 3 dimensions with 22 valid items, namely, use of influence strategy $(n=8$ items, Cronbach's Alpha $=0.71)$; sees and act on opportunity $(n=7$ items, Cronbach's Alpha $=0.72)$, and achievement $(n=7$ items, Cronbach's Alpha $=0.78)$. 
Suryani et al. (2021) successfully constructed a short entrepreneurship competence scale based on a situational judgment test; however, the extended version of the instrument is still crucial. The more detailed competence information may help the researcher develop a more comprehensive curriculum and modules for intervention. The current study was intended to test whether the long version scale is valid through some examinations, namely, internal and external criterion validity. The internal criterion was relevant to the validity of items, and the external criterion was correspondent to the validity of the whole scale. Furthermore, the instrument is needed to be proven whether it can predict the achievement of the entrepreneurs. Hence, the research question in this current study was the instrument valid in terms of construct and predictive validity?

\section{Literature review}

\section{Entrepreneurship competence}

Competence is a standard (primary) characteristic of an individual that can predict a person's work behavior and performance. Fundamental character means a character that does not change in various conditions or situations and lasts a very long time (Spencer \& Spencer, 1993). According to Chouhan and Srivastava (2014), competence is a collection of individual behaviors that can be observed and play an essential role in achieving the desired work result. It combines knowledge, skills, abilities, personal characteristics, and other individual factors that distinguish superior performance from average performance in certain specific situations (Prihadi, 2004). Rivai and Sagala (2014) describe competence as a characteristic. The individual basic skills associated with effective performance or superior competencies are different from other average competencies. In conclusion, competence is the essential characteristic (covering knowledge, abilities, and attitudes) that should be provided to do a job; it can distinguish superior work performance and predict a person's behavior in various situations.

Schumpeter (1965) defined an entrepreneur as an individual who exploits market opportunity through technical and organizational innovation. Whereas Arafeh (2016) described an entrepreneur as someone who can identify and generate competitive business ideas, utilize resources, regulate the production of goods, promote products or services, manage various kinds of risks, and continue to work for business growth and excellence. According to Soegoto (2014), entrepreneurs are creative and innovative people who can establish, build, develop, advance, and make their company superior. Other definitions characterized entrepreneurs as individuals who are very passionate about what they do and are willing to take risks to transform their dreams into realities (Shefsky, 2011). They are sensitive, create and respond to change regarding a possible opportunity for profit, anticipate, and build a credible vision of their future business (Therin, 2019). They also see everything as an opportunity to modify items that were initially ordinary to something new.

Spencer and Spencer (1993) initially explained 20 entrepreneurial competencies; however, after conducting a series of researches, they concluded 13 entrepreneurial competencies, namely, (1) initiative, sees and act on opportunities, (2) persistence, (3) information seeking, (4) concern for the high quality of work, (5) commitment to work hard, (6) efficiency, (7) systematic planning, (8) problem solving, (9) self-confidence, (10) persuasion, (11) use of influence (12) influence strategies, and (13) assertiveness. 
Detailed definitions by Spencer and Spencer (1993) of each dimension are described as follows. Initiatives are actions to exceed what is needed or demanded by the work/environment and do something without waiting for instructions. Sees and act on opportunities are identified from the accuracy of seeing opportunities that are not always seen but can be found if they were examined carefully. Persistence describes a person's endurance when facing challenges and difficulties, and s/he decides to persevere and keep trying, even though facing failure after failure. Information seeking can be seen from the additional effort spent to gather more information for work and decision-making. An individual who concerns the high quality of work shows high motivation to ensure the quality of work or products under his/her responsibility. Commitment to working hard is the drive and ability of a person to adjust his behaviors to the organization's needs, priorities, and goals; to act in a way that supports the achievement of organizational goals. This commitment includes the act of making a personal sacrifice or being willing to do more to finish the job, taking full responsibility for completing the work for the customer, encouraging colleagues to complete the work, and showing concern to achieve customer satisfaction. Efficiency orientation is a degree of concern in an individual's work so that s/he is motivated to work more efficiently. Systematic planning is shown by understanding a situation or problem from a holistic perspective and identifying complex cases' central/underlying problems. Problem-solving is the ability to understand the situation by resolving it into more detailed parts (factors) to achieve the goals. Selfconfidence is a person's belief in one's own ability to complete a task/challenge/work. Persuasion is a person's ability to influence and convince others to act according to what is expected. Influencing strategies is an ability to use various strategies to influence others and understand to implement a specific strategy for certain people. Assertiveness is a drive and willingness to act as a group leader, usually indicated in a position of formal authority.

\section{Construct and criteria related to entrepreneurship Risk-taking behavior}

According to Fischhoff (1992), risk-taking behavior in a risky situation, where this situation contains a high level of uncertainty and is likely to cause losses. Astamoen (2005) defined risk as an opportunity for something unexpected to occur and includes an option for loss. Risk is an inherent characteristic of all strategic decisions in that there is some degree of uncertainty associated with decision outcomes, and some outcomes are more desirable than others. As evidenced in a broad-based body of research, risk affects decision behaviors by influencing perceptions of the decision situation, evaluating alternatives, choices made, and other decision-related actions taken in response to risk (Pablo et al., 1996, p. 724). In an entrepreneurial context, risk-taking behavior is inherent and the nature of its activities (Busenitz, 1999). According to Macko and Tyska (2009), entrepreneurship is considered riskier than other professions. There seems to be general agreement that risk-bearing is necessary for an entrepreneur. Kacmar (2002) stated that a risk-taker must know possibilities for alternative decision-making choices, because choices can result in potential losses or losses.

According to Fischhoff (1992), there are three dimensions of risk-taking behavior: decision-making, courage to act, and the ability to bear losses. Decision-making is a 
cognitive aspect involving awareness that the growth of business comes from taking opportunities and risks. When a risky decision is made, individuals consider the consequences of the behavior. Courage to act is an affective aspect that an entrepreneur must be persistent and courageous, open to opportunities, and solve problems before they even happen. The ability to bear loss or risk is an affective dimension that an entrepreneur must bear the possible dangers of taking personal responsibility for his actions by reducing dependence on other parties.

Guo and Jiang (2020) stated that risk-taking in an entrepreneurial context refers to a firm's willingness to engage in calculated business-related risks. It is typically characterized by making significant resource commitments to entrepreneurial activities that involve a higher likelihood of high payoff and costly failure, embracing uncertainties, and breaking away from the tried and true. Risk-taking has long been recognized as a typical trait of entrepreneurs. Wang and Poutziouris (2010) showed that risk-taking intensity correlates with business performance. It means that risk-taking behavior is relevant to business success in entrepreneurship. Kozubíková et al. (2017) show the result of their research about financial risk and personality traits that most entrepreneurs consider the importance of financial risk to increase during the crisis period. The results also show that the entrepreneurs try to minimize the financial risk through building up reserves concerning such qualities as "risk-taking" and "decisiveness" in comparison to a rather negative attitude to "optimism."

\section{Business success}

The traditional model of measuring success in any business organization is often seen straightforwardly in the profit and loss statement (Voisey, et al., 2006). The business's success should be identified from many aspects (Zimmerer et al., 2008). According to Machado (2013) and Soderberg et al. (2011), the first performance evaluation models were based solely on financial measures. Over time, countless critics of those models appeared, causing the theory to currently give supremacy to performance evaluation models that simultaneously include financial and non-financial measures. The most adequate that simultaneously have financial and non-financial measures to measure business success is the Balanced Scorecard. Kaplan and Norton (1996), Gumbus and Lussier (2006), and Giannopoulos et al. (2013) measure business success from four perspectives, namely, financial, customer, innovation process, and learning and growth perspective. Janjic et al. (2012) recommends using the customer's perspective, internal processes, learning and growth, and financial perspective. This research will use three aspects from this theory: financial elements, innovation process aspects, and customer aspects (Kaplan dan Norton, 1996).

\section{Construct validity}

Construct identification validity aims to see whether a test tool has fulfilled its function in measuring constructs or traits theoretically (Anastasi \& Urbina, 1997). Cohen and Swerdlik (2017) mention several methods that can be used in testing construct validity that can help gather evidence that:

a. The test is homogeneous only measures one construct (internal consistency). 
b. The test score increases in line with the development of the mental function, which is influenced by age (developmental changes).

c. The test score will change because of the experience between the pretest and posttest. The intervention carried out is a construct that the researcher wants to measure. (experiment intervention).

d. Testing the instrument on two groups with contrasting traits will result in significantly different test scores (contrasted group method).

e. The test score will be correlated with other test scores that theoretically measure the same construct (convergent validation) and will have a low correlation with other test scores that theoretically measure different constructs (discriminant validation).

f. The subtest score on a series of tests has a loading factor that can describe a particular trait/construct (factor analysis).

The validity examination comprised the internal and external criteria validity methods to identify the construct and predictive validity. A statistical method, namely, confirmatory factor analysis (CFA), was implemented to test the construct validity at the internal level. Another method is correlations with other tests (measuring the same construct) to test the construct validity for the external level. In the current study, exploring new dimensions on which is usually conducted by implementing exploratory factor analysis (EFA), was not the goal. The CFA was chosen to maintain the number of dimensions as many as possible (as close as possible to the original number recommended by Spencer and Spencer (1993)).

As an internal validity examination approach (Cohen \& Swerdlik, 2017), the CFA applied in this study was conducted at the dimension level. This analysis was to examine the relationship of the items toward their dimension rather than to the whole scale. The initial method may suggest eliminating a significant number of dimensions. It was assumed that each measurement is independent of the other. Furthermore, this approach was considered superior to the simple item-total correlation examination, because it involves the dimension scores in latent variables rather than observed scores. The latent trait was considered as the true score in the psychological measurement.

Arpiainen and Kurczewska (2017) and Antoncic et al. (2018) stated that risk-taking behavior is the key competence to entrepreneurship. The entrepreneurship construct should include this critical ability. Therefore, the construct validity test should identify whether the instrument has a significant relationship with risk-taking behavior. A more straightforward method to examine the construct validity of an instrument is to test its correlation with another tool measuring the same construct (Anastasi and Urina, 1997). Hence, the external validation included a correlation test between the current instrument with the previously available scale, namely, self-assessment entrepreneurial competence with Likert-scale model provided by Riyanti and Suwartono (2018) (Table 1), and risk-taking behavior developed by Riyanti (2006) based on Fischhoff (1992) (Table 2). The self-assessment entrepreneurial competence and risk-taking behavior. were constructed involving Indonesian culture; hence, this scale was relevant with the current instrument. The risk-taking behaviour scale was used in this study, because the fundamental competence of entrepreneurship is risk-taking behavior (Busenitz, 1999). 
Table 1 Items of self-assessment perceived entrepreneurial competencies (Riyanti \& Suwartono, 2018)

\begin{tabular}{ll}
\hline No & Item statements \\
\hline 1 & Knowing how to make something more precious and valuable \\
2 & Develop existing opportunities \\
3 & Search for and collect as much information \\
4 & Responsible for my work \\
5 & Thinking logically and systematically \\
6 & Having excellent analyses capability \\
7 & Finding innovative solutions to a problem \\
8 & Analyzing a problem \\
9 & Looking for some approaches to problem-solving \\
10 & Eliminating the adverse judgment of others against me \\
11 & Fostering cooperation for the attainment of a goal \\
12 & Managing resources \\
13 & Task delegation \\
14 & Creating a marketing strategy \\
15 & Specify the market options \\
16 & Creating a product marketing team \\
17 & Determining the type of goods/services produced \\
18 & Determining the number of goods produced \\
19 & Make a variety of different types of products \\
20 & Adjusting the production schedules \\
21 & Planning a stock of goods \\
22 & Organizing the division of labor \\
23 & Determining the types of archives/records \\
24 & Making work rules \\
\hline &
\end{tabular}

\section{Predictive validity}

This validity analysis aims to see the effectiveness of the test in predicting individual performance in certain activities (criteria). Measurement of the predicted criteria that can be done at the same time as data collection for the test is referred to as concurrent validity or is postponed at certain time intervals, which is called predictive validity (Anastasi \& Urbina, 1997). In certain situations, especially when the time interval for data collection criteria is considered too far, concurrent validity can be used as a substitute for predictive validation. If this is done, then this validity test is carried out using a sample group that already has criteria data when the test is carried out. The criteria that are usually used in this test include academic performance, such as school report scores, student GPA, work performance in employee groups, ratings from superiors, diagnosis and prognosis of psychiatrists, training instructor ratings, etc. (Anastasi \& Urbina, 1997). In this study, we will use business success as the criteria to be predicted by our instrument, since one of entrepreneurship competence's outcomes is organization performance ( $\mathrm{Ng} \&$ Kee, 2013).

\section{Research method}

\section{Participant}

The participants $(\mathrm{N}=149)$ were recruited via convenience sampling using paper \& pen questionnaires as well as an online questionnaire from several provinces in Indonesia, 
Table 2 Items measuring risk taking behavior (Riyanti, 2006)

\begin{tabular}{|c|c|}
\hline No & Item statements \\
\hline 1 & I dare not take risky opportunities in my business \\
\hline 2 & It is better for me to take safe action than to take risky actions \\
\hline 3 & I am not interested in taking any action that is risky \\
\hline 4 & I can take responsibility for the risks that will occur \\
\hline 5 & I will not allow myself to take any risky actions \\
\hline 6 & Financial risk is something that I have to bear in my business \\
\hline 7 & For me, making risky decisions will cost me more \\
\hline 8 & I used to take risky actions in facing intense market competition \\
\hline 9 & I hold other people accountable for the risky actions I took \\
\hline 10 & I will not take risky decisions that will affect the production process \\
\hline 11 & Taking responsibility for risky actions is foolishness \\
\hline 12 & I am willing to take a risky choice in facing competition \\
\hline 13 & I rely on other people to cover the losses for my risky actions \\
\hline 14 & I do not like to take risky actions in running a business \\
\hline 15 & I will not run away from responsibility after doing something risky \\
\hline 16 & I was unable to take responsibility for the risky actions I had taken \\
\hline 17 & I do not dare to bear the loss if there is an accumulation of goods in the warehouse \\
\hline 18 & I will choose to make safe decisions over risky decisions \\
\hline 19 & I will not allow others to take the risk of the actions I have taken \\
\hline 20 & I did nothing to risk my actions \\
\hline 21 & I feel pessimistic about making risky decisions \\
\hline 22 & I will not take any risky action against business competitors \\
\hline 23 & I insist on maintaining risky actions in the midst of uncertainty \\
\hline 24 & I can't afford to make risky decisions \\
\hline 25 & It never crossed my mind to make a risky decision \\
\hline 26 & I often shy away from the responsibility of taking on business risks \\
\hline 27 & I often make risky decisions to develop my business \\
\hline 28 & I feel that a risky decision can actually advance my business \\
\hline 29 & I am willing to pledge my house to the bank to get business capital \\
\hline 30 & For me, making a risky decision is a symbol of hopelessness \\
\hline 31 & I feel satisfied after taking risky actions in running my business amidst the uncertainties \\
\hline 32 & For me, I can bear all business risks \\
\hline 33 & I am able to take responsibility for the risks that occur \\
\hline 34 & Financial risk is something I have to bear in running my business \\
\hline 35 & I hold other people accountable for the risky actions I took \\
\hline
\end{tabular}

namely, Jakarta (63.76\%), West Java (34.90\%), Gorontalo (0.67\%), and Riau (0.67\%). Many SME owners in Indonesia are not registered in SME associations; therefore, we have difficulty using the probability sampling method. Although they were recruited by a non-probability approach, the selection was conducted carefully. All participants should meet the criteria of Small and Medium Enterprises by the Indonesian government. The requirements are: having been doing business for at least 3 years with a minimum profit of IDR 20 million (USD 1,400) per month, and the business is still active when they fill the instrument. The participants were male (55.03\%) and held bachelor's degree $(67.11 \%)$. The other participants were junior high school (2.01\%), high school graduates $(26.19 \%)$, and hold master's degree $(4.69 \%)$. They were an entrepreneur in the field of food and beverages, fashion, car repair shop, transportation service, health 
products, electronic products. They were relatively young, with mean of age was 33 years $(\mathrm{SD}=10.88 ;$ Median $=30 ;$ Mode $=24)$.

\section{Instruments}

\section{Indonesian entrepreneurial competence inventory-situational judgment test model}

The current study was a continuation of Suryani, Riyanti, and Sandroto study (submitted). In their research, 63 items measuring entrepreneurial competence comprising 12 dimensions in a situational judgment test model were written. The item contained a short story of an entrepreneur facing business problems (cases derived from interviews with entrepreneurs and validated by experts in entrepreneurship) and followed by multiple solutions. An example of the question and choices are as follows: "Ray is a new entrepreneur; he owns a restaurant for 2 years. One day he felt that his noodle restaurant was less attractive to customers. He wants to do something for his restaurant to make it better and attract customers' attention. What should Ray do?" A. Add a more varied menu and improve the quality of taste (score 1); B. Redesigning the restaurant to make it look more hygienic, excellent, and affordable, and looking for a more strategic location even though this will require more funds (score 2), C. Promoting through social media accounts and posting noodle photos that look appetizing (score 3), D. Endorse to food bloggers, because the testimonials of these parties have an impact on increasing sales, because they have their followers (score 4).

\section{Construct validity}

(a) the self-assessment measuring instrument for entrepreneurial competence was compiled by Riyanti and Soewartono (2018) based on the theory of Spencer and Spencer (1993) and from the theory of Chou et al. (2010). Initially, this instrument consisted of 137 items, with 13 soft skills and five complex skills. The confirmatory factor analysis results showed 24 items (Cronbach's Alpha=0.95) forming three dimensions: business management, strategic thinking skills in Indonesia to manage a business, and the ability to see opportunities. All dimensions are valid and reliable. An example of the items of this scale is "Use multiple approaches to solve problems" with seven alternative responses from "I feel very not competence" (score 1) until "I feel very competent (score 7).

(b) risk-taking behavior scale consists of 35 items measuring 3 dimensions, namely, decision making (Cronbach's Alpha $=0.76)$, courage to act Cronbach's Alpha $=0.82$ ), and able to take risks developed (Cronbach's Alpha =0.70) by Riyanti (2006). An example of this scale is "I used to take risky actions in the face of intense market competition" with the alternative response from "Strongly disagree" (score 1) and "Strongly agree" (score 5).

\section{Predictive validity}

Business success consists of 16 items measuring the achievement at the current state compared to the condition when the business was initiated. The items were constructed based on Kaplan and Norton (1996). An example of the items is: "How does your average number of customers compare to when your business was established?" The alternative response are: decreased (score 0), the same (score 1), increased 1-25\% (score 3), 
increased 26-50\% (score 4), increased 51-75\% (score 5), increased 76-100\% (score 6), increased more than $100 \%$ (score 7).

\section{Results}

\section{Construct validity}

Internal validity

The Indonesian Entrepreneurial Competence Inventory was tested by applying confirmatory factor analysis for each dimension. The result showed that nine dimensions with 42 items were valid (see Tables 3 and 4) with acceptable goodness of fit. Three dimensions had unacceptable goodness of fit: self-confidence, concern for the high quality of work, and care. These three dimensions were dropped. The Cronbach's Alpha of the remain dimensions was relatively low $\left(\alpha=0.48-0.70 ; \mathrm{M}_{\alpha}=0.57\right)$. However, the low coefficient of Cronbach's Alpha did not mean the poor precision of the measurement. Sorrel et al. (2016) explained that the characteristic of SJT measures multidimensional aspects of the item. This characteristic is an opponent to Cronbach's Alpha which examines the homogeneity of the items. Sorrel et al. (2016) suggested using the test-retest reliability method for the SJT test.

\section{External validity}

The external validity examination involved correlation testing with a previously available test, namely, self-assessment entrepreneurial competence (Likert-scale model) (Riyanti \& Suwartono, 2018)) and Risk-Taking Behaviour (Riyanti, 2006). The results were presented in Table 5. In the correlation between dimensions of current inventory and previous scale, it was found that only dimension of commitment to work hard has a significant correlation with two dimensions of the previous test. The dimension were: ability to see an opportunity $(r=0.32, p<0.01)$ and ability to think strategically $(0.22$, $p<0.01)$ and with total competence $(r=0.22, p<0.01)$. Other dimensions that were correlated with the ability to see opportunity were assertive and persuasion.

The correlation between dimensions of current inventory and dimensions of risk-taking behavior showed that almost all dimensions correlated with risk of decision making, except the dimension of efficiency-oriented. In correlation with dimension of courage to act from dimension of risk-taking behaviour, the significant correlation were found with dimension of assertive $(r=0.19, p<0.05)$, commitment to work hard $(r=0.20, p<0.05)$, persuasion $(r=20, p<0.05)$, and systematic planning $(0.22, p<0.05)$. All correlations were significant in correlation with taking the risk and total score of risk-taking behavior, except the correlation with seeing and acting on the opportunity dimension.

\section{Predictive validity}

The predictive validity was examined by implementing correlation testing between dimensions of current inventory with business success. The results revealed that all dimensions in the current inventory were correlated significantly with business success, except the seeing and acted on opportunity dimension (see Table 5). This finding showed that entrepreneurial competencies play a role in business success, as Ng and Kee (2013) mentioned. Furthermore, competencies in this instrument will be used for curriculum development. 
Table 3 Confirmatory factor analysis of the Indonesian entrepreneurial competence inventory

\begin{tabular}{|c|c|c|c|c|c|c|c|c|}
\hline Domain & $x^{2}(d f)$ & $\mathrm{p}$ & CFI & TLI & GFI & RMSEA & $\lambda$ items & $\begin{array}{l}\text { Reliability } \\
\text { (Cronbach's } \\
\text { Alpha) }\end{array}$ \\
\hline 1. Assertive & $0.94(1)$ & 0.33 & 1.00 & 1.00 & 1.00 & 0.00 & $\begin{array}{l}A 1=0.54 \\
A 2=0.35 \\
A 3=0.33 \\
A 4=0.24\end{array}$ & 0.48 \\
\hline 2. Commitment to work hard & $0.78(1)$ & 0.38 & 1.00 & 1.00 & 1.00 & 0.00 & $\begin{array}{l}\text { CTW1 }=0.77 \\
\text { CTW2 }=0.44 \\
\text { CTW3 }=0.72 \\
\text { CTW4 }=0.82\end{array}$ & 0.50 \\
\hline 3. Efficiency oriented & $7.79(8)$ & 0.44 & 1.00 & 1.00 & 0.98 & 0.00 & $\begin{array}{l}\mathrm{EO} 1=0.30 \\
\mathrm{EO} 2=0.44 \\
\mathrm{EO} 3=0.45 \\
\mathrm{EO} 4=0.48 \\
\mathrm{EO} 5=0.60 \\
\mathrm{EO} 6=0.56\end{array}$ & 0.58 \\
\hline 4. Initiative & $2.20(2)$ & 0.33 & 1.00 & 0.99 & 0.99 & 0.00 & $\begin{array}{l}11=0.43 \\
12=0.77 \\
13=0.64 \\
14=0.70\end{array}$ & 0.69 \\
\hline 5. Persistence & $10.36(8)$ & 0.24 & 0.98 & 0.97 & 0.98 & 0.04 & $\begin{array}{l}\text { PSTC1 }=0.67 \\
\text { PSTC2 }=0.43 \\
\text { PSTC3 }=0.45 \\
\text { PSTC4 }=0.37 \\
\text { PSTC5 }=0.83 \\
\text { PSTC6 }=0.51\end{array}$ & 0.70 \\
\hline 6. Persuasion & $3.39(4)$ & 0.50 & 1.00 & 1.00 & 0.99 & 0.00 & $\begin{array}{l}\text { PER1 }=0.31 \\
\text { PER2 }=0.44 \\
\text { PER3 }=0.71 \\
\text { PER4 }=0.32 \\
\text { PER5 }=0.37\end{array}$ & 0.51 \\
\hline 7. Problem Solving & $6.27(7)$ & 0.51 & 1.00 & 1.00 & 0.99 & 0.00 & $\begin{array}{l}\text { PS1 }=0.66 \\
\text { PS2 }=0.64 \\
\text { PS3 }=0.41 \\
\text { PS5 }=0.45 \\
\text { PS6 }=0.39\end{array}$ & 0.65 \\
\hline 8. See and Act on Opportunity & $1.78(2)$ & 0.41 & 1.00 & 1.00 & 0.99 & 0.00 & $\begin{array}{l}\mathrm{SAO} 1=0.38 \\
\mathrm{SAO} 2=0.86 \\
\mathrm{SAO}=0.22\end{array}$ & 0.60 \\
\hline 9. Systematic Planning & $4.76(5)$ & 0.45 & 1.00 & 1.00 & 0.99 & 0.00 & $\begin{array}{l}\mathrm{SP} 1=0.35 \\
\mathrm{SP} 2=0.41 \\
\mathrm{SP} 3=0.82 \\
\mathrm{SP} 4=0.58 \\
\mathrm{SP} 5=0.38\end{array}$ & 0.67 \\
\hline
\end{tabular}

Recommendation: $p$ value $>0.05 ; \mathrm{GFI}, \mathrm{AGFI}, \mathrm{TLI}$, dan $\mathrm{CFI}>0.95$; RMSEA $<0.08$

\section{Discussion}

This study aimed at construct and predictive validity examination of the long version of Indonesian Entrepreneurial Competencies Inventory constructed with situational judgment test. The construct validity was examined via internal and external approach by implementing two statistical method, namely, CFA and correlation with other tests. The other test was the entrepreneurial competencies built in a Likertscale model and risk-taking behavior. The predictive validity was examined by applying correlation testing with business success. The result showed that the instrument was valid in measuring the construct of entrepreneurial competence and valid predicting the business success. 
Table 4 Final cases in entrepreneurial competencies inventory

SAO1 At the end of the business leasing period, Aris, who had just opened a business, received information about online business seminars that might help him develop his business. The fee is approximately the same as the cost of renting out the business premises. He hesitated, because the funds he currently has can only be used to select one of the two needs. What should Aris do?

SAO2 One of the businesses that Ani wants to develop is a catering business. In her observations, the existing catering business actors offer food at high prices. What did Ani need to do to make her business successful?

$\mathrm{SAO} 3$ Santi has a business selling various types of women's clothing online. Her customers are working women who have children aged 3-6 years. In 3 years of running the business, she has achieved a satisfying profit. To expand more, what can she do?

EO1 Budi has a business that has developed in a number of cities. In his observations over the last 5 years, his shop in Bangka has experienced continuous losses, while stores in other cities have experienced a profit. What should Budi do?

EO2 Yuli has been in the sleepwear business for 3 years. In her sales for the last 1 year, it was found that 85\% of buyers prefer nightwear with dark color choices. There are even special requests that order dark color clothes. What should Yuli do?

E03 Lisa is a new entrepreneur producing women's clothes and accessories. After selling for several months, she realized that the accessory products were not selling well. This pushed her to sell accessories products at low prices, hence she often experiences losses. What should Lisa do?

EO4 Rina's salon printing business is one of the businesses affected by the monetary crisis. At that time, Rina suffered a loss, because orders to print banners were low. What should Rina do?

EO5 James is the owner of a photo studio and wedding photography services. When he opened his business, James had very little capital. What should James do?

EO6 Mario's consulting company was one of the companies affected during the economic crisis. At that time, many of his clients canceled their orders. His clients also have difficulty paying the orders. It makes his financial situation getting down. What should Mario do?

PSTC 1 Cahyo has a snack food supplier business. The customer is the owner of outlets or shops. They pay Cahyo for the goods sold at their outlet or shop, if the goods are not sold within the specified time, the goods are returned to Cahyo. At one point, some of his customers went bankrupt and had not paid for or returned goods. What should he do?

PSTC 2 Dini has a list of 20 farmers in West Java who can become suppliers of agricultural products that are important to her business. However, after visiting 15 farmers, she found that they had all become suppliers to other companies. She still has 5 other farmer names that can be visited. What should he do?

PSTC 3 Feri continues his father's business which has been running for 10 years as a men's clothing reseller. After 1 year, he ran the business, he realized his business was less profitable. He noticed that his suppliers were starting to supply women's clothing and offering lower reseller prices for these clothes. What should he do?

PSTC 4 Rachel opened an online shop that sells make-up with a pre-order system, where customers have to pay down payment of $30 \%$ of the price of goods. She has only been in this business for 6 months. One day there was a customer who did not pay off her payment, where the remaining bill was two million rupiah. Rachel was unable to contact the customer. Because of this incident she suffered a loss. What are the next steps Rachel should take?

PSTC 5 Gio has a business selling cellphone cases online by relying on his acquaintances on his social media accounts. After 3 months of being in business, the number of his customers have not increased and the capital has not returned. Gio began to feel bored with his selling activities. What should he do?

PSTC 6 Toni is a service and goods entrepreneur. The business he is in is growing rapidly, so he needs a new office to run his business. However, it was difficult for him to find a place that was neither too expensive nor too big to serve as an office. What should he do?

11 The current business situation is marked by global competition by e-commerce companies. As a businessman, how do you respond to this?

12 When you are visiting your boutique in a mall, you see many customers who have not been served by your employees because of the limited number of employees. As the owner of the boutique, what should you do in that situation?

13 Ray is a new entrepreneur; he owns a restaurant for 2 years. One day he felt that his noodle restaurant was less attractive to customers. He wants to do something for his restaurant to make it better and attract customers' attention. What should Ray do?

14 Jeni is the owner of a bakery in a shopping centre. After opening her bakery for several months, Jeni realized that the shopping centre was empty of visitors. What should Jeni do?

SP1 You will get an investment of $50 \%$ of your profit given by foreign investors. How do you allocate your finances to advance the business you are running? 
Table 4 (continued)

SP2 Lukito's business began to grow. It has 3 employees. Lukito feels he needs several employees in other fields to strengthen his business performance. However, he realized, from the existing business cash, there was no way he could recruit all the employees he wanted at one time. What should he do?

SP3 lis, a successful businessman, often uses Z's laundry service which is located near his house. Laundry owner Z is a college friend. lis sees that Z's laundry has advantages compared to 3 other laundry around his house. Laundry $Z$ provides a price that is slightly cheaper than its competitors and the service is faster. However, Z laundry doesn't have a comfortable outlet atmosphere and its customers are just that. lis saw a pretty good opportunity if Laundry $Z$ wanted to improve the condition of its outlets and wanted to invite cooperation. What should he do?

SP4 Yuli is a clothing businessman in Tanah Abang, Yuli is faced with a situation, where unsold clothes are increasingly piling up in warehouses and must be sold all not to lose. what steps should Yuli take in such a situation?

SP5 Tania is a canteen food entrepreneur. However, she was cheated by employees who were her trusted people. What should she do?

PER1 As a vegetable and coconut distributor, Dito finds difficulty to receive trustworthy employees and is overwhelmed if he has to teach them from the start. What should he do?

PER2 AAC store is a family business founded by $A$ and financed by his parents. There are different views between $A$ and his parents, according to A's parent the use of bookkeeping records (financial flow) is not necessary, even though according to A bookkeeping records are an important business instrument. What should A do?

PER3 Bubu is ready to run a snack supplier business. He has also prepared a list of shops that he will visit. He has been digging up information on the store supplier, his prospect, giving the same price as him. What should he do when he visits these shops?

PER4 Yoyo is an entrepreneur providing agricultural produce that has grown rapidly in the past 2 years. His business was developed from Yoyo's personal funds, so far it has made a profit. However, the funds raised are still unable to be used to expand Yoyo's business. One day Yoyo heard that two of his friends were planning to invest their money. What should he do?

PER5 Mr. Roy suffered a loss for his business and had to lay off several of his employees. However, Mr Roy needs time to pay his employees severance pay. How does Mr. Roy explain to his employees?

CMTW1 Yanuar has two different businesses. He realized that in the next 6 months, his new business needed to be more focused. What did Yanuar need to do?

CMTW2 Ibnu is the owner of a snack distribution business. Currently, Ibnu also works permanently in a company as a Marketing Staff. It works Monday to Friday, 8am to $5 \mathrm{pm}$. Since working, many of his snack employees were confused, because they felt they lacked direction from Ibnu. What should he do?

CMTW3 Joni is a cell phone shop owner. One day, there was a theft at his shop. This made Joni suffer losses, because he lost hundreds of cell phones. What should Joni do?

CMTW4 Devi is a Korean restaurant owner. She often gets complaints from her customers, because sometimes the taste of the food is different and not up to standard. This happens, because the chef does not realize that the taste of the food is unstandardized. What should Devi do?

PS1 TB Butanah is a soil material company located in Sukabumi. Many of the TB Butanah consumers reside in Jakarta. What needs to be done by the management of TB of Northern TB to cut shipping routes that are too far away?

PS2 Employees at Pipit's laundry business make mistakes that have happened repeatedly. The error is related to how the employee receives and handles customer complaints. So far, Pipit only told her employees verbally how to handle customer complaints. What should she do?

PS3 Keke has a business to supply hospital equipment and necessities. It has been 3 months, since one of Keke's regular customer hospitals always made payments 7 days past the due date. The hospital also did not pay the fine, even though Keke had already given a letter. Keke and the hospital agreed from the start that monthly payments were sent on the 20th, and there was a penalty for late payment. This situation disrupted Keke's company cash flow. What should he do?

PS5 As a canteen food entrepreneur, Tania suffered a loss. This is because the types of food are not varied, and the food portions are too small. What should she do?

PS6 Vita is an online fashion entrepreneur. So far, her supplies goods from Thailand to be sold in Indonesia. Recently, she has had a problem when the goods she is selling are stuck at customs. To get the goods, she needs to pay more. What should she do?

A1 Didi has a business in architecture. In several development projects in the last 6 months, he encountered obstacles, because his colleagues had different views from him, where his views were very risky. This partner has a large enough share for this business. What attitude does Didi need to show to his colleague? 
Table 4 (continued)

A2 Mario is one of the owners of a consulting service company. At one point, Mario provided services to
a client and imposed an instalment payment system. At first, the client pays, but over time the client
does not pay and runs away. This makes Mario's company suffer a loss. What should Mario do?
Dodi as a grocery store owner provides an instalment payment system to his customers. However,
often customers who are given instalment will take a long time to pay and get angry when they are
billed. What should Dedi do?
As an optical goods business owner, Feli prioritizes hospitality when serving her customers. However,
not all his employees are friendly when serving the customers. This makes customers feel uncomfort-
able and do not want come back to shop in his optics. What should Feli do?

Table 5 Correlation coefficient between dimensions of entrepreneurial competences (current and previous scale), dimensions of risks, and business success

\begin{tabular}{lccccccccc}
\hline Dimensions & $\mathbf{1}$ & $\mathbf{2}$ & $\mathbf{3}$ & $\mathbf{4}$ & $\mathbf{5}$ & $\mathbf{6}$ & $\mathbf{7}$ & $\mathbf{8}$ & $\mathbf{9}$ \\
\hline Assertive & $0.22^{* *}$ & 0.02 & 0.16 & 0.14 & $0.37^{* *}$ & $0.19^{*}$ & $0.35^{* *}$ & $0.39^{* *}$ & $0.25^{* *}$ \\
Commitment to work hard & $0.32^{* *}$ & $0.22^{* *}$ & 0.15 & $0.22^{* *}$ & $0.32^{* *}$ & $0.20^{*}$ & $0.30^{* *}$ & $0.35^{* *}$ & $0.34^{* *}$ \\
Efficiency oriented & -0.02 & 0.08 & -0.11 & -0.04 & 0.15 & 0.10 & $0.18^{*}$ & $0.19^{*}$ & $0.16^{*}$ \\
Initiative & 0.04 & -0.03 & -0.15 & -0.09 & $0.21^{*}$ & 0.07 & $0.34^{* *}$ & $0.29^{* *}$ & $0.32^{* *}$ \\
Persistence & 0.10 & 0.01 & -0.04 & 0.00 & $0.29^{* *}$ & 0.11 & $0.44^{* *}$ & $0.38^{* *}$ & $0.37^{* *}$ \\
Persuasion & $0.25^{* *}$ & 0.11 & 0.03 & 0.10 & $0.32^{* *}$ & $0.20^{*}$ & $0.44^{* *}$ & $0.43^{* *}$ & $0.46^{* *}$ \\
Problem-solving & 0.12 & 0.07 & -0.09 & -0.01 & $0.23^{* *}$ & 0.09 & $0.36^{* *}$ & $0.31^{* *}$ & $0.37^{* *}$ \\
See and act on opportunity & 0.02 & 0.06 & 0.03 & 0.04 & $0.19^{*}$ & 0.06 & 0.12 & 0.15 & 0.11 \\
Systematic planning & 0.10 & 0.07 & -0.10 & -0.01 & $0.36^{* *}$ & $0.22^{*}$ & $0.46^{* *}$ & $0.46^{* *}$ & $0.38^{* *}$ \\
Total the Indonesia & 0.15 & 0.08 & -0.04 & 0.04 & $0.35^{* *}$ & $0.18^{*}$ & $0.45^{* *}$ & $0.44^{* *}$ & $0.41^{* *}$ \\
Entrepreneurial & & & & & & & & & \\
Competence SJT model & & & & & & & & & \\
\hline
\end{tabular}

1. Ability to see opportunity; 2 . Ability to think strategically; 3 . Ability on business management; 4 . Total Entrepreneurial Competence; 5 . Risk Decision Making; 6. Courage to act; 7. Able to take risk; 8. Total Risk Taking behaviour; 9 . Business Success. ${ }^{*} p<0.05 ;{ }^{* *} p<0.01$

The results revealed that the long-version of this inventory was valid, measuring nine dimensions of entrepreneurial competencies with 43 items. The dimensions were assertiveness, commitment to work hard, efficiency-oriented, initiative, persistence, persuasion, problem-solving, see and act on opportunity, and systematic planning. Items from the other three dimensions, namely, self-confidence, concern for high quality of work, and care, were not valid and dropped. The Cronbach's Alpha, a type of internal reliabilities that usually following internal validity analysis, disclosed that the items were inconsistent measuring their dimensions. It is understandable, because the form of situational judgment test provides a multidimensional measure in a single item (Catano et al., 2012; Schmidt \& Hunter, 1996; Sorrel et al., 2016). It was suggested to use test-retest reliability to measure its consistency (Catano et al., 2012).

The examination of the construct validity through correlation with risk-taking behavior scale showed that the current inventory was valid at the level of whole test and dimensions, except dimension of seeing and act on the opportunity. In general, this finding is relevant to Guo and Jiang (2020) that risk-taking behavior was identical with entrepreneurs.

The predictive validity revealed that the current inventory was valid in predicting business success at the level of whole test and dimensions, except dimension of seeing 
and act on the opportunity. It proves that items measuring competency in the cases related to risk processes in business management. Therefore, for someone who has a high score in this instrument shows a high level of entrepreneurial risk-taking behavior. Later on, it can have a significant impact on business success.

The hard correlation between the current inventory and previous entrepreneurial competence is probably because the competencies were measured. The current inventory was constructed in the SJT model, which involved experience both in stimulus and responses in the item, whereas the previous test measured the participant's perception to what extent they perceived that they could do the entrepreneurship activities. The current inventory was considered more relevant with competency measurement, while the previous scale was more related to the perception of competence.

This study also found that the dimension of seeing and acting on the opportunity was hardly related to other measurements. There are some possibilities; first, the cases measuring see and act on the opportunity in the instrument were not involving risky behavior. Second, all the participants were in the small and medium business category; it is assumed that even though they were able to see the opportunity, they do not dare to take the risk. They do not have the modal and facilities (most of them use their limited modal for their business). Third, the participants focused more on maintaining their business than looking for development or building a new business.

\section{Implication}

The current competence inventory is based on real cases in the business world that entrepreneurs face. From this instrument, it can be seen to what extent the potential for entrepreneurial competence can be mapped on which dimensions they are strong and which dimensions still need to be improved. Dimensions that are still weak can become areas of intervention through training. Entrepreneurs can study these cases to further increase their knowledge as entrepreneurs. As for theoretical development, this study provides evidence that entrepreneurial competencies were associated with risk-taking behavior and business success. This finding strengthening previous studies on the same field (e.g., Macko \& Tyszka, 2009; Ng \& Kee, 2013; Wang \& Poutziouris, 2010).

The results of this study provide opportunities for the emergence of new competent entrepreneurs when participating in practice-based entrepreneurship education programs. It includes curriculum designs that hone knowledge, attitudes and skills as an entrepreneur. These three things are the basic characteristics that make up competence.

\section{Conclusion}

The current study provided evidence that the Indonesian Entrepreneurial Competence Inventory-SJT Model can be used to develop an education program for entrepreneurs, since it was proven overlapping with risk-taking behaviour that is the core of entrepreneurial competence entrepreneurship and predicting the business success of entrepreneurs. However, this measuring tool is one of the factors for assessing the potential for entrepreneurial competence. However, for an entrepreneur to be successful, it needs to be equipped with entrepreneurial knowledge from various sources: attending formal education, improve job experience, coaching, and mentoring (Noe, 2020). No less important is mastery of the business field (Robbins \& Coulter, 2018). 
Entrepreneurs who have the potential for high entrepreneurial competence must research the business they are engaged in by understanding and answering the questions: who are the customers? Where are they? At what price will they be willing to buy the product? Who are the competitors? How is the product differentiated from competitors' products? (see Ebert \& Griffin, 2015).

The principles in business that apply in general, namely, in management, no one best way (Robbins \& Coulter, 2018), also apply to the situational measurement tools we have developed. This measuring tool must frequently be up to date with the latest business cases, because business conditions change rapidly, so that entrepreneurial cases relevant in current conditions are not necessarily relevant in future business conditions.

The business organization is an open system, which is influenced by external factors. Entrepreneurs need to scan for external conditions that can affect the success of their business. The Pestel framework suggests six organizational environmental factors, namely, political, economic, social, technological, and legal conditions, that can affect business success. Entrepreneurs must always diagnose change. Other several tools for diagnosing changes are scenario analysis, gap analysis, strategy, and many others (Palmer et al., 2009).

The business world is increasingly competitive, technology is growing. Entrepreneurs not only have to be competence, they also need to continue to hone their technological skills and implement innovations. The global and competitive landscape has been transformed by the role of knowledge and innovation. One area that has seen exponential growth due to the increase in innovation is in technology (Kraus et.al., 2021). The government plays a major role in creating an environment that supports innovation. One of the successful implementation of this program is the State of Japan. Kazakhstan applies a similar pattern of support as Japan in creating an innovative environment conducive to business development (Sadyrova, et al., 2021).

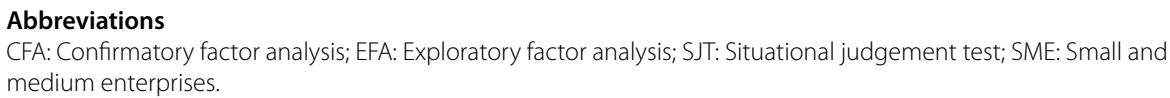

\section{Acknowledgements}

We would like to appreciate the Indonesian Chamber of Industry and Commers (Kamar Industri dan Dagang Indonesia) for their support in collecting data.

\section{Authors' contributions}

BPDR was writing the introduction, literature review, item writing preparation, discussion, and conclusion. AOS was writing the item writing, method, and data analysis. CWS was writing the literature review and data collection. SYS was writing literature review and data collection. All authors read and approved the final manuscript.

\section{Authors' information}

BPDR received her doctorate from University of Indonesia focusing on entrepreneurship. Her professorship in entrepreneurship was received in 2009 from Atma Jaya Catholic University of Indonesia. Her areas of expertise include, but are not limited to psychometric and psychological assessment, professional development, and educational entrepreneurship.

\section{Funding}

The research was funded by The Fund of Decentralization Research: Basic Research of Excellence in Higher Education from The Ministry of Research and Indonesian Higher Education 2019-2021. Kementerian Riset,Teknologi dan Pendidikan Tinggi (ID), 93.ADD/LL3/PG/2020, Benedicta Prihatin Dwi Riyanti

\section{Availability of data and materials}

The data sets generated and/or analysed during the current study are not publicly available due to the informed consent signed by participant mentioning the data particularly only for the current research but are available from the corresponding author on reasonable request. 


\section{Declarations}

Ethics approval and consent to participate

The participant was signing the form of Inform consent in the questionnaire by writing their initial in the form. The statement of the inform consent was "I declare that I am willing to participate in this research. I acknowledge that the data I provide will be kept confidentially and will only be used for the purposes of this research."

\section{Competing interests}

The authors declare that all of the authors have no competing interests.

\section{Author details}

${ }^{1}$ Atma Jaya Catholic University of Indonesia, Jakarta, Indonesia. ${ }^{2}$ Pancasila University, South Jakarta, Indonesia.

Received: 21 December 2020 Accepted: 12 January 2022

Published online: 25 January 2022

\section{References}

Anastasi, A., \& Urbina, S. (1997). Psychological Testing (7th ed.). Prentice-Hall.

Antara. \& Setiawan, K. (2018, 24 July). Menkominfo Rudiantara: Konektivitas Kunci Revolusi Industri 4.0 [Minister of communication and information Rudiantara: Connectivity is the key to Industry Revolution]. Bisnis Tempo. https://bisnis.tempo.co/read/1110063/menkominfo-rudiantara-konektivitas-kunci-revolusi-industri-4-0.

Antoncic, J. A., Antonic, B., Gantar, M., Hisrich, R. D., Marks, L. J., Bachkirov, A. A., Li, Z., Polzin, P., Borges, J. L., Coelho, A., \& Kakkonen, M.-L. (2018). Risk-taking propensity and entrepreneurship: The role of power distance. Journal of Enterprising Culture, 26(1), 1-26. https://doi.org/10.1142/S0218495818500012

Arafeh, L. (2016). An entrepreneurial key competencies' model. Journal of Innovation and Entrepreneurship, 5(26), 1-26. https://doi.org/10.1186/s13731-016-0048-6

Arpiainen, R.-L., \& Kurczewska, A. (2017). Learning risk-taking and coping with uncertainty through experiential, team-based entrepreneurship education. Industry and Higher Education, 31(3), 143-155. https://doi.org/10.1177/ 0950422217700994

Astamoen, M. P. (2005). Entrepreneurship dalam perspektif kondisi bangsa Indonesia [Entrepreneurship in the perspective of Indonesian]. Bandung: Alfabeta.

Busenitz, L. W. (1999). Entrepreneurial risk and strategic decision making: It's a matter of perspective. The Journal of Applied Behavioral Science, 35(3), 325-340. https://doi.org/10.1177/0021886399353005

Catano, V. M., Brochu, A., \& Lamerson, Ch. D. (2012). Assessing the reliability of situational judgment tests used in high-stakes situations. International Journal of Selection and Assessment, 20(3), 333-346. https://doi.org/10.1111/j. 1468-2389.2012.00604.x

Chou, C. M., Shen, C. H., Hsiao, H. C., \& Chen, S. C. (2010). A study on constructing entrepreneurial competence indicators for business department students of vocational and technical colleges in Taiwan. World Transactions on Engineering and Technology Education, 8(3), 316-319.

Chouhan, V. S., \& Srivastava, S. (2014). Understanding competencies and competency modeling - A Literature Survey. IOSR Journal of Business and Management, 16, 14-22. https://doi.org/10.9790/487X-16111422

Cohen, R. J., \& Swerdlik, M. E. (2017). Psychological testing and assessment (9th ed.). UK: McGraw-Hill Education.

Cronk, L. (2017). Culture's influence on behavior: steps toward a theory. Evolutionary Behavioral Sciences, 11(1), 36-52. https://doi.org/10.1037/ebs0000069

Ebert, R. J., \& Griffin, R. W. (2015). Business essential (10th ed.). Pearson.

Fischhoff, B. (1992). Risk taking: A developmental perspective. In J. F. Yates (Ed.), Wiley series in human performance and cognition. Risk-taking behaviour (pp. 133-162). John Wiley \& Sons.

Giannnopoulos, G., Holt, A., Khansalar, E., \& Cleanthous, S. (2013). The use of the balanced scorecard in small companies. International Journal of Business and Management., 8(14), 1-22. https://doi.org/10.5539/ijbm.v8n14p1

Gumbus, A., \& Lussier, R. (2006). Entrepreneurs use a balanced scorecard to translate strategy into performance measures. Journal of Small Business Management, 44, 407-425. https://doi.org/10.1111/j.1540-627X.2006.00179.x

Guo, Z., \& Jiang, W. (2020). Risk-taking for entrepreneurial new entry: Risk-taking dimensions and contingencies. International Entrepreneurship and Management Journal, 16, 739-781. https://doi.org/10.1007/s11365-019-00567-8

Irene, B. N. O. (2017). A cross-cultural assessment of the competency needs of women operating in the context of SMEs in South Africa. Mediterranean Journal of Social Sciences, 8(1), 20-30. https://doi.org/10.5901/mjss.2017. v8n $1 \mathrm{p} 20$

Janjic, G., Tanasic, Z., \& Benea, M. (2012). Improvement of the system of business success measurement in a company using multicriteria decision-making method. Annals of the Faculty of Engineering Hunedoara, 10(1), 159-165.

Juliana, N., Hui, H., Clement, M., Solomon, E., \& Elvis, O. (2021). The impact of creativity and innovation on entrepreneurship development: evidence from Nigeria. Open Journal of Business and Management, 9, 1743-1770. https:// doi.org/10.4236/ojbm.2021.94095

Kacmar, M. (2002). An investigation of the determinant of investment risk behavior in employer-sponsored retirement plans. Journal of Management, 28(1), 3-26.

Kaplan, R. S., \& Norton, D. P. (1996). The Balanced Scorecard: Translating strategy into action. Harvard Business School Press.

Kozubíková, L., Dvorský, J., Cepel, M., \& Balcerzak, A. P. (2017). Important characteristics of an entrepreneur in relation to risk taking: Czech Republic case study. Journal of International Studies, 10(3), 220-233. https://doi.org/10. 14254/2071-8330.2017/10-3/16 
Kraus, S., McDowell, W., Ribeiro-Sorianoc, E. R., \& Rodríguez-García, M. (2021). The role of innovation and knowledge for entrepreneurship and regional development. Entrepreneurship \& Regional Development. https://doi.org/10. 1080/22797254.2021.1872929

León, J. A. M., \& Gorgievski, M. (2007). Psychology of Entrepreneurship Research and Education. . Polígono Igarsa Paracuellos de Jarama.

Machado, M. J. C. V. (2013). Balanced Scorecard: An empirical study of small and medium size enterprises. Revista Brasileira De Gestao De Negocios Review of Business Management, 15(46), 129-148.

Machmudin, B. (2017, 18 December). Ketika presiden berbagi pengalaman jadi wirausaha [When the president shares his experience as entrepreneur]. Protocol, Press, and Media Division of the Presidential Secretariat, Ministry of Communication and Information of the Republic of Indonesia. https://m.kominfo.go.id/content/detail/ 12074/ketika-presiden-berbagi-pengalaman-jadi-wirausaha/0/berita.

Macko, A., \& Tyszka, T. (2009). Entrepreneurship and risk taking. Applied Psychology: An International Review, 58(3), 469-487. https://doi.org/10.1111/j.1464-0597.2009.00402.x

Man, T. W. Y., \& Lau, T. (2005). The context of entrepreneurship in Hong Kong: An investigation through the patterns of entrepreneurial competencies in contrasting industrial environments. Journal of Small Business and Enterprise Development, 12(4), 464-481.

$\mathrm{Ng}, \mathrm{H}$. S., \& Kee, D. M. H. (2013). Effect of entrepreneurial competencies on firm performance under the influence of organizational culture. Life Science Journal, 10(4), 2459-2466.

Noe, R. A. (2020). Employee Training and Development (8th ed.). Mc Graw Hill.

Pablo, A. L., Sitkin, S. B., \& Jemison, D. B. (1996). Acquisition decision-making processes: The central role of risk. Journal of Management, 22(5), 723-746.

Palmer, l., Dunford, R., \& Akin, G. (2009). Managing organizational change: A multiple perspectives approach (2nd ed.). McGraw-Hill.

Prihadi, S. F. (2004). Assessment centre-identifikasi, pengukuran, dan pengembangan kompetensi [Assessment center: competencies identification, measurement, and development]. Gramedia Pustaka Utama.

Rivai, V., \& Sagala, E. J. (2014). Manajemen sumber daya manusia untuk perusahaan [Human resources management for corporate] (3rd ed.). Rajawali press.

Riyanti, B. P. D. (2006, August 18-20). Women entrepreneurs profile: a preliminary study [Paper presentation]. The First Convention of the Asian Psychological Association (APsyA), Bali, Indonesia.

Riyanti, B. P. D., \& Soewartono, C. (2018). Psychometric evaluation of newly developed self-assessment of entrepreneurial competencies. International Journal of Apllied Business and International Management, 3(1), 1-13.

Robbins, S. P., \& Coulter, M. (2018). Management (14th ed.). Pearson International Edition.

Sadyrova, M., Yusupov, K., \& Imanbekova, B. (2021). Innovation processes in Kazakhstan: development factors. Journal of Innovation and Entrepreneurship. https://doi.org/10.1186/s13731-021-00183-3

Schmidt, F. L., \& Hunter, J. E. (1996). Measurement error in psychological research: Lessons from 26 research scenarios. Psychological Methods, 1(2), 199-223. https://doi.org/10.1037/1082-989X.1.2.199

Schumpeter, J. A. (1965). Economic theory and entrepreneurial history. In H. G. Aitken (Ed.), Explorations in enterprise. Cambridge: Harvard University Press.

Shefsky, L. (2011). Entrepreneurs are made not born. McGrawHill.

Soderberg, M., Kalagnanam, S. S., Norman, T., \& Vaidyanathan, G. (2011). When is Balanced Scorecard a Balanced Scorecard? International Journal of Productivity and Performance Management, 60(7), 688-708.

Soegoto, E. S. (2014). Entrepreneurship Menjadi Pebisnis Ulung [Entrepreneurship becoming an excellent businessperson]. Elex Media Komputindo.

Sorrel, M. A., Olea, J., Abad, F. J., de la Torre, J., Aguado, D., \& Lievens, F. (2016). Validity and reliability of situational judgement test scores: A new approach based on cognitive diagnosis models. Organizational Research Methods, 19(3), 506-532. https://doi.org/10.1177/1094428116630065

Spencer, L. M., \& Spencer, S. M. (1993). Competence at work. John Wiley \& Sons.

Suryani, A. O., Riyanti, B. P. D., \& Sandroto, C. W. (2021). The construction of entrepreneurial competence test: Situational judgement test model. Academy of Entrepreneurship Journal, 27(5), 1-11.

Therin, F. (2019). Handbook of research on techno-entrepreneurship (3rd ed.). Elgar Publishing.

Voisey, P., Gornall, L., Jones, P., \& Thomas, B. (2006). The measurement of success in a business incubation project. Journal of Small Business and Enterprise Development, 13(3), 454-468.

Wang, Y., \& Poutziouris, P. (2010). Entrepreneurial risk-taking: empirical evidence from UK family firms. International Journal of Entrepreneurial Behaviour \& Research, 16(5), 370-388. https://doi.org/10.1108/13552551011071841

Wulani, F., Lindawati, T., Putro, A. J. W. T., \& Suhartatik, A. (2019). Scale development of entrepreneurial competency of SME owner in Indonesia. Academy of Entrepreneurship Journal, 25(4), 1-12.

Zimmerer, T., Scarborough, N. M., \& Wilson, D. (2008). Essentials of entrepreneurship and small business management. Pearson/Prentice Hall.

\section{Publisher's Note}

Springer Nature remains neutral with regard to jurisdictional claims in published maps and institutional affiliations. 